\title{
Factors Impacting Work Family Balance of Working Mothers
}

\author{
Arri Handayani \\ Universitas PGRI Semarang
}

\author{
Tina Afiatin, M.G.Adiyanti, and Fathul Himam \\ Universitas Gadjah Mada Yogyakarta
}

\begin{abstract}
Most working women find it difficult to get work-family balance because when they are in one domain, the other suffers. Work-family balance will be useful for organization, family, and the individual himself. This research was aimed at finding out factors that influence workfamily balance of working mothers in Semarang, using descriptive qualitative method. The research subject was selected using purposive technique with informant characteristics as follow: working mother, working husband, living together with husband, and having child under 18 years old. Based on the research result, it was revealed that there are six factors influencing work-family balance, either from internal or external factors. Internal factors that influence work-family balance are commitment, understanding towards women's role, and individual's character. Meanwhile, external factors that influence work-family balance are social support, either from husband, family, supervisor, or colleagues, the presence of a child, and working autonomy.
\end{abstract}

Keywords: work-family balance, working mother

\begin{abstract}
Sebagian besar perempuan yang bekerja sulit mencapai keseimbangan kerja dan keluarga, karena ketika berada dalam ranah kerja maupun keluarga, ada satu sisi yang diuntungkan, tetapi di sisi lain ada sesuatu yang harus dikorbankan. Padahal, dengan adanya keseimbangan kerja keluarga akan bermanfaat untuk organisasi, keluarga dan individu itu sendiri. Penelitian ini bertujuan mengetahui faktor-faktor yang memengaruhi keseimbangan kerja keluarga ibu bekerja di kota Semarang. Metode yang digunakan adalah deskriptif kualitatif. Subjek penelitian dipilih dengan menggunakan teknik purposive dengan karakteristik informan, ibu bekerja, suami juga bekerja, tinggal serumah dengan suami, dan mempunyai anak di bawah 18 tahun. Berdasarkan hasil penelitian terungkap enam faktor yang memengaruhi keseimbangan kerja-keluarga, baik yang berasal dari faktor internal maupun faktor eksternal. Faktor internal yang memengaruhi adalah komitmen, memahami peran perempuan dan karakter individu. Sementara itu, faktor eksternal yang mempengaruhi adalah dukungan sosial, baik berasal dari suami, keluarga, atasan, rekan kerja, keberadaan anak, dan otonomi kerja.
\end{abstract}

Kata kunci: keseimbangan kerja dan keluarga, ibu bekerja

While working women are becoming more common, the fact is that these women face more conflicts com-pared to working men - mostly caused by role differences between men and women in the family. These are the findings of Kinnunen and Mauno (1998); Martins, Eddleston, and Veiga (2002), and Agung (2004). These differences are caused by more flexibilities for men in their family roles, while women's are more routine, such as their respon-

Correspondence concerning this article should be addressed to Arri Handayani, FIP Universitas PGRI, Semarang, Jalan Sidodadi Timur No 24, Dr. Cipto Semarang 50125 Jawa Tengah. E-mail: arri.hdy@ gmail.com sibilities towards their children particularly those under 12 (Ahmad, 2005; Ford, 2007). As such, while working, women are still required to meet these domestic responsibilities towards the household and children. This means, women have dual roles.

These dual roles have caused women problems in achieving work-family balance. While in one role, the other suffers. This has been studied by Keene and Quadagno (2004), who argued that $60 \%$ of working adults find it difficult to reach work-family balance, particularly working couples with children under 18. 
In terms of definition of work-family balance, this article refers to when a mother has to divide her time, attention and energy, as well as producing satisfactory results, so that her work and home responsibilities are properly done (Handayani, Afiatin, \& Adiati, 2015).

Work-family balance benefits the organization, family, and the individuals. From the organization's point of view, work commitment and productivity should increase (Grzywacz \& Marks, 2000), as well as a high organizational citizenship behaviour (Bragger, Rodriguez-Srednicki, Kutcer, Indovino, \& Rosner, 2005). The individual worker's balanced life will contribute to individuals' prosperity, good health, and their well-functioning in the society (Halpem, 2005), while from the family perspective there will be family satisfaction, marriage satisfaction, family performance, well-functioning family (Carlson, Kacmar, Wayne, \& Grzywacz, 2006), family prosperity (Greenhause, Collins, \& Shaw, 2003) as well as the happiness of working mothers (Afiatin, Wintoro, Bulo, Ulfa, \& Istianda, 2014).

With all these in mind, the authors conducted an exploratory research about the factors affecting work-family balance, with focus on working mothers in Semarang city, which has collectivistic culture and patrilinial. Such characters are important for this study as existing ones are mostly from Western culture which tends to be more individualistic. As such, this study aims to explore the factors that play a role in impacting work-family balance for working mothers in Semarang.

\section{Work Family Balance}

According to Grzywacz \& Carlson (2007) the first concept of work-family balance and most widely used refers to the concept of the absence of work-family conflict. As such, at the time of previous researches, most of the literature on this topic discussed the conflicts for working families.

As research on this topic progresses, the absence of conflict alone is insufficient in showing the existence of work-family balance (Grzywacz \& Carlson, 2007; Valcour, 2007). Grzywacz \& Carlson (2007) argue that the work-family balance appears from the positive and negative aspects of work-family interface. Meanwhile, Washington (2006) opinionated that negative aspects always uses conflict concepts, while for positive aspects a few terms have been used such as work family enrichment, work family interface, work family facilitation, positive family spillover.
Based on Marks and MacDermid (1996); Greenhause, Collins and Shaw (2003); and Clark (2000), it can be deduced that work-family balance in essence is the involvement and satisfaction of the same roles in the work and family domains with minimal conflict. A study done by Handayani et al (2015) shows that the meaning of work-family balance is when a mother can divide time, attention, and energy and produce satisfactory results, so that work and household tasks are completed well. This study refers to Handayani et al. (2015) for definition of work-family balance.

\section{Factors Impacting Work Family Balance}

Literature review of empirical studies on role conflicts and role balance suggests that studies on role balance involve many programs offered by organizations for their workers to balance their roles. According to Muchinsky (2003) for the last two decades, organizational research has been focused a lot on problems to do with work and organization, which it tends to ignore elements on variable from the family domain.

As such, studies on role balance has more to do with antecedents such as satisfaction towards intervention programs offered by organizations (Burchielli, Bartram \& Thanacoody, 2008; Lyness \& Kropf, 2005; Saltzstein \& Saltzstein, 2001), or personal (Lyness \& Kropf, 2005). Be that as it may, there are internal and external factors, from family and organizations, which impact work-family balance. According to literature review internal factors include personality (Bulgan, 2011; Valcour, 2007; Wierda-Boer, Gerris, \& Vermulest, 2008), age (Lyness \& Kropf, 2005), perception towards gender role (Bulgan (2011); communication (Helmle, 2010), adaptive strategies (Wierda-Boer et al., 2008), commitment towards roles (Beutell, 2007; Helmle, 2010), role involvement (Frone, 2003), career experience (Eddleston \& Powell, 2012; Lyness \& Judiescch, 2008) and autonomy (Beutell, 2007).

External factors of family include child's existence (Greenhause, Ziegert, \& Allen, 2011), family involvement (Saltzstein \& Saltztein, 2001), family support (Eddleston \& Powell, 2012; Greenhause, Ziegert, \& Allen, 2011), responsibilities towards children (Hill, Märtinson, \& Ferris, 2004), responsibilities towards parents (Ellwart \& Konradt, 2011; Hill et al., 2004), family demands (Ellwart \& Konradt, 2011), and conflicts of working families (Greenhause et al., 2011). 
External factors from organization include work culture (Clark, 2001), work involvement (Rotthbard, 2001; Saltzstein \& Saltztein, 2001), social support (Adam, King, \& King, 1996; Beham \& Drobnic, 2009; Ferguson, Carlson, Zivnuska, \& Whitten, 2012; Valcour, 2007), work family conflict (Greenhause et al., 2011), working hour flexibility (Lyness \& Kropf, 2005) and work demands (Beham \& Drobnic, 2009; Ellwart \& Konradt, 2011; Saltzstein \& Saltztein, 2001).

\section{Method}

This study employs descriptive method with qualitative approach, which is an analysis that describes thoroughly and sistematically, and the data are presented without using statistical and measurement formulas. This method is a procedure that results in descriptive data which are words from interviews and Focus Group Discussions (FGD) about factors impacting work-family balance. Data were obtained from the daily lives of this study's informants.

The study was conducted for eight months, starting August 2013 until April 2014. The location for this study is Semarang. Informants of this study are working mothers with various professional backgrounds such as banking, administration, teachers, lecturers, and entrepreneurs. The decision to involve working mothers from various backgrounds is aimed at obtaining a complete description of the factors impacting their work-family balance, and the efforts to achieve work-family balance for the working mothers. The informants were chosen with purposive sampling, which were working mothers, with working husbands, living under one roof with the husbands, and have children under 18.

Data analysis technique are: (1) process and prepare data for analysis; (2) read the data in complete; (3) analyse in detail by coding the data; (4) implement the coding process to describe setting, people, categories, and themes that will be analysed; and (5) demonstrate how the description and themes will be presented in a qualitative report (Creswell, 2010).

\section{Results}

Based on the analysis of interview results and FGDs, the authors present the description and analysis of data, which covers: (1) Informant descriptions; and (2) Factors impacting work-family balance.

\section{Description of Informants}

The informants in this study are 20 working mothers in Semarang, aged between 27-46, with average age of around 30 . Most of the informants are lecturers (six people), and teachers (four people), administration clerk (five people), while the rest are bank clerks and entrepreneurs (two people each), and a human resource manager.

In general informants have no more than three children. Seven of them have one child each, while ten have two children, and three have three each. From the children's age, most informants have children under five years of age, at least one, while there are four informants without children under five.

\section{Factors Influencing Work Family Balance}

Based on the categorization results on factors influencing work-family balance, it has been revealed that there are six of these internal and external factors. The internal factors are commitment, understanding towards the role of women, and individual characters. The external factors are social support (from husband, supervisor, colleagues); child's existence, and work autonomy.

The bases for categorizing the factors are the respondents themselves. Most respondents stated that factors influencing the balance in both work and family domains are social support, commitment to succeed in both domestic and public roles. In terms of commitment, respondents always try to be responsible to achieve success in the two roles. Meanwhile, others stated that the factors for success in work and family are work autonomy, the importance of children, individual characters, and understanding towards the role of women.

These results are in line with previous studies on social support (Adam et al., 1996; Beham \& Drobnic (2009); Ferguson et al., 2012; Valcour, 2007), family support (Eddleston \& Powell, 2012; Greenhause et al., 2011), commitment towards role (Beutell, 2007; Helmle, 2010), work autonomy (Beutell, 2007). Values on children, child's presence (Greenhause et al., 2011), individual character and personality (Bulgan, 2011; Valcour, 2007; Wierda-Boer et al., 2008), and understanding womens' roles towards 
Table 1

Categories of Respondents' Answers

\begin{tabular}{|c|c|c|}
\hline No & Respondent's Answers & Categories \\
\hline 1 & Husband's support & \\
\hline 2 & Husband willing to share role, mind child & \\
\hline 3 & Share all problems to husbands & \\
\hline 4 & Finding the right way to overcome problems together with husband & \\
\hline 5 & Family support & Social support \\
\hline 6 & Parent's motivating to work & \\
\hline 7 & Supervisor's support & \\
\hline 8 & Supervisor gives permission to leave work when child is sick & \\
\hline 9 & Friend's support & \\
\hline 10 & Commitment with husband for quality time & \\
\hline 11 & Focus and responsibility towards work and family & Commitment to succeed in \\
\hline 12 & Implementing priority scale & domestic and public roles \\
\hline 13 & Conducting work as planned & \\
\hline 14 & Conducting work while child sleep while maintaining own health & \\
\hline 15 & Time management & \\
\hline 16 & Children are priceless pearls & \\
\hline 17 & Children are everything & \\
\hline 18 & Children are outlets for love & \\
\hline 19 & Children encourages working mother to go home quicker & \\
\hline 20 & Children are the most precious treasure & Values on children \\
\hline 21 & Children are gifts, temporary responsibility from God & \\
\hline 22 & Everything will be done for the children & \\
\hline 23 & Personality types & \\
\hline 24 & Temperamental and impatient & Individual characters \\
\hline 25 & Optimistic & \\
\hline 26 & Assertiveness & \\
\hline 27 & $\begin{array}{l}\text { Not forgetting women's supposed roles and maintain responsibilities towards } \\
\text { household matters and child rearing }\end{array}$ & \\
\hline 28 & $\begin{array}{l}\text { Women are wives and mothers who should be responsible towards families, } \\
\text { especially husbands and children }\end{array}$ & $\begin{array}{l}\text { Understanding towards the } \\
\text { role of women }\end{array}$ \\
\hline 29 & Maintaining honour as wives & \\
\hline 30 & Flexible time management & \\
\hline 31 & Own management of work time & Work autonomy \\
\hline 32 & Work autonomy & \\
\hline
\end{tabular}

gender roles (Bulgan, 2011) all influence workfamily balance. Table 1 describes categorization of respondent's answers. Mean-while, here are detailed descriptions of those factors:

\section{Social Support}

All respondents stated that social support has an important role in achieving work-family balance. Support in this context means help, particularly from husbands.

The following is a quote from a respondent: "Definitely husband's support ma'am... Imagine if a husband does not support a wife's activity, inside or outside the home. For sure there will be argument which could lead to marriage failure or career. Husband (should be) willing to share roles, minding children for instance (if) on offdays we have activities outside the home."

"Yang pasti dukungan suami buu.... Bayangkan seandainya suami tidak mendukung aktivitas istri, baik di rumah maupun di luar rumah. Pasti yang ada percekcokan yang berujung pada kegagalan keluarga ataupun karier. Suami rela berbagi peran, menjaga anak misalnya ketika hari libur terpaksa kita harus beraktivitas di luar rumah."

Other respondents stated that:

"My husband is remarkable. He always supports me. To my husband I always share my problems..., because that is where I found the right way to 
overcome my problems. Actually my problems don't always get solved... But when I told my husband... I feel relieved... I even feel that I won't be this way without him. He teaches me to see things positively."

"Suami saya adalah orang yang hebat. Dia selalu mendukung saya. Kepada suami juga saya ceritakan seтua permasalahan saya...,karena dari situ saya merasa menemukan cara yang pas untuk mengatasi masalah saya. Sebetulnya masalahnya tidak selalu selesai yaaa.... Tapi ketika saya cerita ke suami... rasanya kayak plong gitu.... Bahkan saya merasa tidak akan seperti ini tanpa dia. Dia yang mengajari saya untuk selalu melihat sesuatu dari sisi positif."

In relation to family support, respondents said that when there is work to be brought home, family can provide support by taking turns caring for the children. Meanwhile, other respondents have said that, parents, particularly mothers are very supportive of respondents to work.

“Husband role is very big ma'am... My mother's role as well. My mother is most supportive of me working, because my mom wanted me to work. Because with a job (we) have power towards men... So if unwanted things happen we can survive and not just twiddling our thumbs. Because my mother is so supportive, so she also helps minding my children when I am at work. So we take turns mam... myself, my husband, my mother take turns minding my children."

"Peran suami begitu besar bu.... Peran mama saya juga. Mama yang paling mendukung saya untuk bekerja, karena mama yang mewajibkan saya untuk bekerja. Karena dengan bekerja punya wibawa bagi pria.... Jadi sewaktu-waktu ada hal-hal yang tidak diinginkan kita bisa tetap survive dan tidak berpangku tangan saja. Karena mama sangat mendukung, maka mama juga yang membantu menjaga anak ketika saya di kantor. Jadi gantian bu... saya, suami, mama yang gantian jaga anak saya."

In relation to support from supervisors and friends, respondents stated that support from supervisor and friends are also influential, but not as big as husband and family support. Here is a quote from this interview.
"I think, support from supervisor and friends are also influential mam... but not as big as husband's or family's. For instance, when a child is sick, a worker is not allowed to mind that child at home, which surely will interrupt the house and office work. Usually... the supervisor will provide a policy on rights and duties in accordance with the regulations..., so I think it is husband's support and then family are still most important."

"Menurut saya, dukungan atasan dan teman berpengaruh juga bu... tetapi tidak sebesar dukungan suami ataupun keluarga. Misalnya, ketika anak sakit, sebagai karyawan tidak diizinkan untuk menunggu anak di rumah, pasti akan mengganggu kinerja baik di rumah maupun di kantor. Biasanya sih... atasan akan memberikan kebijaksanaan hak dan kewajiban sesuai dengan ketentuan yang ada..., jadi menurut saya tetap dukungan suami lalu keluarga yang lebih utama."

\section{Commitment}

Respondents' answers that can be included into the commitment category, among others are focus and concentration towards existing work, not delaying work, conducting routine in accordance to plan although difficult, conducting work at home while children are asleep while maintaining own health. Other commitments include implementing priority scales, as keeping work demand at all times will be endless. Improving time management, so that at home can really take care of the household, so that husband and children can feel a mother's presence, while try to complete all work planned targets at the office.

Respondents said that mutual commitment between wife and husband to allocate some quality time will influence the work-family balance. Here is the quote from the respondent:

"Mutual commitment to allocate some quality time is important ma'am... Although maybe it is not much, but we both try to maintain the quality of the little time we have together. The problem is that my husband travels out of town a lot..., so we try to make use of what little time we have."

"Komitmen bersama untuk meluangkan waktu berkualitas itu penting buu.... Meskipun mungkin secara kuantitas sedikit tetapi kita bersama berusaha menjaga kualitas pertemuan yang sedikit 
itu. Masalahnya suami saya sering ke luar kota..., jadi kami berusaha memanfaatkan waktu yang sedikit itu."

Meanwhile, other respondent said that the commitment was aimed for the wife's commitment to be responsible for her roles at work and home. Having a family and work is a choice, so when that choice was made, the wife should be responsible for both. Such condition is reflected in the quote below.

"Um... well, so working is a choice. I mean, working while having a family is also a choice. So if that is the option, (we) should be responsible not to abandon the family. We are working to support the husband right mam... so let's not let the family be the victim. But yes please do not work carelessly. We should not work all the time, that we forget the family, or vice versa, family become an excuse to not work optimally. In essence, be responsible for both... so both can succeed."

"Ee...gimana yaa... jadi bekerja itu adalah pilihan. Maksudnya berkeluarga sambil bekerja itu pilihan. Jadi kalau itu yang dipilih, harusnya ya bertanggung jawab biar keluarga tidak terlantar. Kita ini bekerja 'kan hanya membantu suami 'kan buu... jadi ya jangan sampai keluarga terus dikorbankan. Tapi ya jangan sampai juga terus kerjanya seenaknya. Jangan sampai karena terus-terusan bekerja, sampai lupa keluarga, atau sebaliknya keluarga dijadikan alasan untuk tidak melakukan pekerjaan dengan optimal. Pokoknya tanggung jawab keduanyalah ... biar sama-sama berhasil."

\section{The Presence of Children}

Respondents have admitted that the presence of children influences work-family balance. Especially when with young children who desperately needs a mother's presence. When a mother leaves for work and the child cries, then it will be difficult to concentrate working at the office. Although respondents revealed various meanings of children, all of them regard children as precious. Some answer that children are everything, a gift to take care, a place to pour love, and so it is because of children that working mothers want to go home quicker, and home is the most previous treasure. They are willing to do anything for their children, as they are precious pearls.

Below is a quote on this issue.
"To me children are like precious pearls... it was difficult for me to conceive mam... so I feel reluctant to leave them. I feel very sad when leaving the house while my child cry wanting to leave with me, I won't be able to concentrate at work. I keep thinking of my child. Meanwhile perhaps he was already feeling better at home..."

"Bagi saya anak itu seperti mutiara yang tak ternilai... saya susah punya anaknya buu... jadi rasanya eman-eman kalo mau ninggalin anak. Saya sedih sekali kalau mau kerja anak klayu ... (menangis dan meminta ikut ke kantor bersama ibu), di kantor pasti tidak bisa konsentrasi. Kepikiran anak terus. Padahal bisa jadi anaknya sudah tidak apa-apa...."

\section{Individual Character}

Individual characters are one other factor that influences work-family influence. Respondents' answer pointed that individual character include assertiveness, bad mood, temperament, and optimistic. Individuals with particular characteristics will find it easier to integrate work demands and family so that work-family balance can be achieved. Respondents say that temperamental and impatient people will influence work-family balance. Below is a quote from an interview.

"Because I easily get into a bad mood at work mam, when situation is tense at work. That is why I choose to ignore when a colleague is talking bad about me behind my back. It is very painful, and I find it difficult to work. I was once ridiculed in front of students. Can a dangdut singer teach? But I tried to maintain my calm in order to balance work mam. I was not like that before mam, I was very temperamental, an impatient woman, and all these influence this balance. Patience and selfcontrol are very important, particularly in socializing and being a good team member."

"Karena saya gampang sekali bad mood bu dalam bekerja jika situasi kantor menegangkan. Maka dari itu saya memilih untuk mendamaikan hati saya jika ada teman sejawat yang menjelekjelekkan di belakang saya. Sakit sekali rasanya, dan saya sulit konsentrasi dalam bekerja. Pernah saya djelek-jelekkan di depan mahasiswa. Penyanyi dangdut apa bisa ngajar? Tapi saya berusaha menjaga kenyamanan hati demi menyeimbangkan 
pekerjaan bu... Dulu saya tidak seperti itu, bu. Dulu saya temperamen sekali... dan wanita yang tidak sabaran... dan ini juga yang memengaruhi keseimbangan. Karena kesabaran, pengendalian diri sangat penting, terutama dalam bersosialisasi dan menjadi team work yang baik."

Other respondents said that an optimistic mother will find it easier to achieve work-family balance as compared to a pessimistic one.

"I am an optimist ma'am.. I am sure that my work and family will be fine. I must be optimistic! Because when I think of what should not happen... or when I think of bad things, then it will also happen. So I would rather be optimistic mam... perhaps because it will bring positive energy..."

"Saya orangnya optimis buu... Saya yakin pekerjaan dan keluarga saya akan baik-baik saja. Saya harus optimis!! Karena ketika saya memikirkan tidak mungkin itu terjadi... atau ketika saya memikirkan hal-hal yang buruk, maka hal buruk itu akan terjadi juga. Jadi saya lebih baik optimis saja buu... kayaknya karena ada energi positif kali yaa...."

\section{Understanding Towards the Role of Women}

Respondents' answer shows that the category of understanding towards the role of women includes not forgetting a woman's role, as well as maintaining responsibility towards household matters and child rearing. A working mother should understand the role of a woman. No matter how hard a woman works, and how much a husband earns, a woman is still a wife and mother who should be responsible towards a family, especially towards husband and children. Below is a quote from a respondent.

"No matter who we are and how much our husband earn, a wife is a wife. A husband is an imam (leader in religion). So at home a wife has to serve husband and children. All these are helpful for me as guidance to build my career. Without these, maybe I will feel guilty and restless in working."

"Siapa pun kita dan seberapa pun penghasilan suami, istri ya tetap istri dan ibu. Suami itu adalah imam. Jadi kalau pulang ke rumah yaa... melayani suami dan anak. Hal itu semua sangat membantu aku untuk bisa membina karier. Kalo tidak ada faktor tersebut, mungkin aku akan merasa bersalah dan tidak tenang dalam bekerja."

Other respondents said that if his wife works, a husband should give trust to work. A husband's trust should be maintained. This means that while working, a wife should keep her honour as a wife and a mother.

"As a career woman, my husband gives trust for me to work. My husband's trust is what I keep mam. This means that I have to maintain my honour as a wife and mother. Especially as a singer mam.. I have also been ridiculed. So I must really keep my husband's trust."

"Sebagai seorang wanita karier, suami saya memberikan kepercayaan kepada saya untuk bekerja. Kepercayaan dari suami itulah yang saya jaga bu. Artinya saya bekerja dengan tetap menjaga kehormatan sebagai istri maupun ibu. Apalagi saya penyanyi buu...saya juga pernah dijelek-jelekkan. Jadi saya harus menjaga betul kepercayaan dari suami."

\section{Work Autonomy}

According to respondents, flexibility or freedom in working will influence work-family balance, although it does not mean that freedom in managing time will guarantee work-family balance. Although respondents answer varied, most respondents believe that freedom in working definitely influences workfamily balance. Respondents answer on this issue include freedom in time management, having own work schedule, a flexible working time division, a working time that can be self-managed, and work autonomy.

Here is a quote from respondent

"If I have a more flexible (work) timing maybe it will be easier to manage work... so that I will have more time for my family. But there are those who don't work at the office... and yet the family also abandoned... so in principle it is up to the mother of course...."

"Kalau saya punya waktu yang fleksibel mungkin lebih mudah untuk mengatur pekerjaan yaa... sehingga keluarga pun juga lebih punya banyak waktu. Tapi ada yang tidak kerja kantoran..., tapi kok keluarganya juga tidak terurus yaa..., jadi intinya kembali pada ibu pastinya.... "“ 


\section{Discussion}

Based on this study we can learn that there are internal and external factors influencing work-family balance. Internal factors originated from the individuals themselves including commitment, understanding towards the role of women, and individual characters. Meanwhile, external factors originated from outside the individuals such as social support, be it from husband, family, supervisor, colleagues, the presence of children, and work autonomy. Below is the discussion of each of these factors.

\section{Social Support}

All of the subjects stated that social support is an important factor to achieve work-family balance as stated by Clark (2000). In this sense, support means help for a working mother which will lighten her dual role. According to respondents, a husband is crucial as the main supporter in working, in providing permission and understanding work demands. Family support is an effective mechanism to reduce conflict and increase work-life balance (Aryee, Srivinas, \& Tan, 2005; Laraseanti \& Aini, 2009; Voidanoff, 2004).

For a working mother, a high personal support, particularly from husband and family members is more valuable than support at the work place (Baran, 2012; Lee, Zvonkovic, \& Crawford, 2013). A spouse is a family element that is most important, as husband and wife interact and share with each other on life experience (Fischlmayr \& Kollinger, 2010; Jianwei \& Yuxin, 2011). As such, a husband's support is crucial for a working mother. Meanwhile, the form of support from a husband among others are when they are willing to share roles, such as minding the child on his day-off because the wife has things to do outside the home. Another form of support mentioned by respondents include when they share their problems with them, whether related to work or family, so that these problems do not prolong and a solution can be found soon, or at least pouring their heart out.

Support at the workplace, such as from supervisor or colleagues, although influencing workfamily balance, is not as crucial as husband's or family's towards work-family balance. This is in line with the studies done by Aryee et al., 2005; Beham \& Drobnic, 2009; Laraseanti \& Aini, 2009; Marcinkus, Berry, \& Gordon, 2006 which found that support at the workplace is related to workfamily balance.
Support at the work place means social support at work that comes from big organizations, supervisor, or colleagues (Marcinkus et al., 2006), who are able to socially interact and connect well interpersonally as well as helping individuals and protect them from stress' negative effects (Nielson, Carlson, \& Lankau, 2001). According to Frone, Yardley and Markel (1997) supervisor and colleagues can provide direct support and advise to help workers to fulfil their family responsibilities and provide emotional support to understand, listen, and show attention towards worker's and their family's prosperity. With these in mind, we can conclude that social support is influential towards workfamily balance.

\section{Commitment}

The respondents said that commitments between husband and wife to allocate quality time will influence work-family balance. Respondent 1 said that although quantitatively small, but when they work together to maintain the quality of this time, it will be very beneficial. Meanwhile, other respondent said that quantity shows greater commitment. In principle, role commitment which was demonstrated by a balance time management between work and family will be better, but if this is difficult, quality can also show role commitment. This is because when one can commit to his role, it will influence work-family balance.

All these are in line with the study by Saginak \& Saginak (2005) which shows that commitment towards work and family roles produce a success in balancing work and family roles. This is because with commitment, a mother will dedicate her time, energy, and mind, to succeed in both roles. A study by Ruderman, Ohlott, Panser, \& King, (2002) shows that women who commit to a variety of roles are more effective in personal and managerial tasks. This condition is caused by the variety of roles provide more opportunities for women to succeed and feel good about herself. As such mothers who can commit will be more successful in balancing work and family.

\section{The Presence of Children}

The presence of children influences work-family balance. For respondents, children are important. Children are pearls, gift to take care of. They are everything. Everything is done for them. Keeping in 
mind these sentiments, when leaving for work mothers must ensure that children are in safe and comfortable conditions - in particular when they are young and mother's presence is highly needed. When they cry during mother's leaving for work, then at the office she will find it difficult to concentrate.

The problem gets more complicated with more than one children, because there will be jealousy and fighting over the mother's attention. As such, the mother needs to divide time for each of the children, as well as for work.

According to Fox, Schwartz, dan Hart (2006), Greenhause et al., (2011), Hill, Hawkins, Ferris, \& Weitzman (2001), there is a close relation between the presence of children and work-family balance. Eddleston \& Powell (2012), Lyness \& Kropf (2005), Olsen \& Dahl (2010), Marcinkus et al., (2006), and McNamara, Pitt-Catsouphes, MatzCosta, Brown, \& Valcour (2012) even argued that couples with young children find it difficult to achieve work-family balance. Valcour (2007) said that the number of children also influences workfamily balance - the bigger the number of children, in particular preschool aged children, the more difficult it gets to achieve work-family balance.

\section{Individual Character}

Individuals with certain characteristics find it easier to integrate work demands and family to achieve work-family balance. Patience and selfcontrol are important in building relationship and teamwork. These characteristics help to complete work. When a mother can complete her work at the office well and quick, she can also finish her household works the same way.

The respondents admitted that temperamental and impatient people will influence work-family balance. An optimistic mother feels that she can complete all her tasks at home and office, so the balance can be achieved. In contrast a pessimistic mother often feels she is incapable, and is afraid to move forward so that time could be wasted and thus the balance is difficult to achieve.

In line with respondents' opinion, Bulgan (2011), and Valcour (2007) argued that one's personality influences work-family balance. Different individuals, when faced with the same situation, can have different perceptions based on their personalities. A particular situation can be perceived as conflict by one individual, but another can see it as a challenge that can enrich one's skills in overcoming family problems. Grzywacz \& Marks (2000) and Wayne, Musisca, and Fleeson (2004)'s studies revealed that one's personality is related to facilitation, a component of work-family balance. As such one's individual character can determine his capacity to achieve this balance.

\section{Understanding Towards Women's Roles}

A working mother must understand a woman's roles. No matter how hard she works, and no matter how much a husband ears, a woman is still a wife and a mother responsible towards the family, in particular towards the husband and children. Although different respondents show different ways to understand this role, most respondents demonstrated that women are women - responsible to family, husband, and children.

While one respondent believes that a mother must cook or care for her own children, others think it is not necessary for her to be in the kitchen - as she can still manage the menu or monitor their children's development while they are being cared for by someone else. Puspitawati (2010) did a study on this matter, and shows that a women have a role as an expressive figure, which function as carer and educator for families, while men are perceived as instrumental figure, who fund family. As such when a mother works, she should still understand her role as a mother and a wife in the family.

Lirio et al. (2007) conducted a study on measuring success for Canadian, Argentinian, and Mexican women, and found that family's long-lasting and endurance, and social support are important for career's success. Indonesia is no different. Puspitawati and Sari (2008) have shown that even in Eastern culture, when a mother works outside she does not abandon her motherly role. As such, it can be said that a woman is demanded to be responsible in domestic sphere. If she does, the work-family balance can be achieved.

\section{Work Autonomy}

According to respondents, flexibility or freedom in working will influence work-family balance. Freedom here means that a mother can have some freedom in arranging her work time, so that when her children need her care such as when they are sick, a mother can be there for them. Meanwhile, when the children are feeling secure and comfortable, a mother should work optimally, and concentrate fully on work. 
Other respondents have said that if a mother is not tied up to a certain institution for her work, it will be easier to achieve work-family balance. However, respondents believe that it all depends on the mother. This means that when a mother works at home and there is no certain rules on working, but her time is spent on work, it is still difficult to achieve the balance.

Along side that, Clark (2001) shows that there is a close correlation between autonomy at work and work-family balance. Hill et al. (2001) and McNamara et al. (2012) also show that work flexibility has a strong and positive impact on work-family balance. Ezra and Deckman (1996) also have the same argument. Organizational support on work flexibility and family needs also have a positive impact on this balance (Thomas \& Ganster, 1995). Still, while freedom and flexibility will help achieve the balance, it still takes a commitment. For instance, even when a mother is an at home entrepreneur, if she has no commitment to achieve this balance, it will be difficult to achieve.

\section{Limitation and Suggestions}

One weakness of this study is that it does not detail husband's occupations, the husband and wife's salaries, and the presence of domestic helper - which all play a role in achieving work-family balance. For instance, if the wife's salary is the main one in the family, her guilt and conflict will be partly overcome. A domestic worker can take up the domestic tasks, so that a mother feels better about leaving home for work. Similarly, the situation will be different If the mother leaves the children with a nanny. Thus, the person caring for the children will also help determine the work-family balance. As such, it is suggested to elaborate and discuss these elements in future studies.

\section{Conclusion, Implication, and Direction for Future Research}

As stated earlier, there are internal (commitment, understanding towards the role of women, and individual characters) and external factors in achieving work-family balance. Commitment and understanding will certainly help, but it all depends on the individual characters as well, as different individual with various characters will take up different attitudes to achieve work-family balance.
Meanwhile, external factors such as social support (from husband, family, supervisor, colleagues, the presence of children, and work autonomy). While social support seems to play the bigger role, the other factors can also determine the achievement of work-family balance.

\section{References}

Adam, G. A., King, L. A., \& King, D. W. (1996). Relationship of job and family involvement, family social support, and work family conflict with job and life satisfaction. Journal of Applied Psychology, 81(4), 411-420.

Afiatin, T., Wintoro, A. Y., Bulo, F. M., Ulfa, L., \& Istianda, I. P. (2014). Kebahagiaan ibu bekerja ditinjau dari rentang kehidupan keluarga (Unpublished research report). Universitas Gadjah Mada.

Agung, M. H. (2004). Konflik kerja-keluarga dan kepuasan kerja akademisi wanita. Ekobis, 3(1), 217-229.

Ahmad, A. (2005). Work family conflict among dual earner couples: Comparisons by gender and profession. Jurnal Psikologi Malaysia, 19, 1-12.

Aryee, S., Srivinas, E. S., \& Tan, H. H. (2005). Rhythms of Life: Antecedent and outcomes of work family balance in employed parent. Journal of Applied Psychology, 90(1), 132-146.

Baran, H. (2012). The role of ethnic culture in work family balance among Armenian women in leadership positions in higher education (Unpublished doctoral dissertation). University of Southern California.

Beham, B., \& Drobnic, S. (2009). Satisfaction with work family balance among German office workers. Journal of Managerial Psychology, 25(6), 669-689.

Beutell, N. J. (2007). Self-employment, work family conflict and work family synergy: Antecedents and consequences. Journal of Small Business and Entrepreneurship, 20(4), 325-344.

Bragger, J. D., Rodriguez-Srednicki, O., Kutcer, E. J., Indovino, L. \& Rosner, E. (2005). Work family conflict, work family culture, and organizational citizenship behavior among teachers. Journal of Business and Psychology, 20, 303-324.

Bulgan, G. (2011). Work family balance and psychososial adjustment of international students (Unpublished doctoral dissertation). Purdue University.

Burchielli, R., Bartram, T., \& Thanacoody, R. (2008). Work family balance or greedy institutions? 
Relations Industrielles/Industrial Relations, 63(1), 108-133

Carlson, D. S., Kacmar, K. M., Wayne, J. H., \& Grzywacz, J. G. (2006). Measuring the positive side of the work-family interface: Development and validation of a work-family enrichment scale. Journal of Vocational Behavior, 68, 131-164.

Clark, S. C. (2000). Work/family border theory: A new theory of work/family balance. Human Relations, 53(6), 747-769.

Clark, S. C. (2001). Work culture and work family balance. Journal of Vocational Behavior, 58, 348365.

Creswell, J. W. (2010). Research design. Pendekatan kualitatif, kuantitatif dan mixed (Ed. Ke-3, A. Fawaid, Pengalih bhs). Yogyakarta: Penerbit Pustaka Pelajar.

Eddleston, K. A., \& Powell, G. P. (2012). Nurturing entrepreneurs' work-family balance: A gendered perspective. Enterpreneurship Theory and Practice, May, 513-541. doi: 10.1111/j.1540-6520.2012.005 06.x

Ellwart, T., \& Konradt, U. (2011). Formative versus reflective measurement: An illustration using work-family balance. The Journal of Psychology, 145(5), 391-417.

Ezra, M., \& Deckman, M. (1996). Balancing work and family responsibilities: Flextime and child care in the federal government. Public Administration Review, 56(2), 174-179.

Ferguson, M., Carlson, D., Zivnuska, S., \& Whitten, D. (2012). Support at work and home: The path to satisfaction through balance. Journal of Vocational Behavior, 80, 299-307

Fischlmayr, I. C., \& Kollinger, I. (2010). World life balance-a neglected issue among Australian female expatriates. The International Journal of Human Resources Management, 21(4), 455-487.

Frone, M. R., Yardley, J. K., \& Markel, K. S. (1997). Developing and testing an integrative model of the work family interface. Journal Vocational Behavior, 50, 145-167

Frone, M. R. (2003). Work family balance. In J. C.Quick, \& L.E. Tetrick (Eds), Handbook of occupational health psychology (pp.143-162). Washington, DC: American Psychological Association.

Ford, M. T, Heinen, B. A., \& Langkamer, K. L. (2007) Work and family satisfaction and conflict: A meta-analisis of cross-domain relations. Journal of Applied Psychology, 92(1), 57-80.

Fox, G., Schwartz, A., Hart, K. M. (2006). Work family balance and academic advancement in medical schools. Academic Psychiatry, 30(3), 227-234.

Greenhaus, J. H., Collins, K. M., \& Shaw, J. D. (2003). The relation between work family balance and quality of life. Journal of Vocational Behavior, $63,510-531$.

Greenhaus, J. H., Ziegert, J. C., \& Allen, T. D. (2011). When family-supportive supervision matters: Relations between multiple sources of support and work family balance. Journal of Vocational Behavior, 80, 266-275.

Grzywacz, J. G., \& Carlson, D. S. (2007). Conceptualizing work-family balance: Implications for practice and research. Advances in Developing Human Resources, 9(4), 455-471.

Grzywacz, J. G., \& Marks, N. F. (2000). Reconceptualizing the work-family interface: An ecological perspective on the correlates of positive and negative spillover between work and family. Journal of Occupational Health Psychology, 5, 111-126.

Halpern, D. F. (2005). Psychology at the intersection of work and family: Recommendations for employer, working families, and policy-makers. American Psychologist, 60, 397-409.

Handayani, A., \& Munawar, M. (2014). Work family balance and quality of parenting in optimizing children development. IJECES Indonesian Journal of Early Childhood Education Studies, 3(2), 1-12

Handayani, A., Afiatin, T., Adiati, M.G. (2015). Studi eksplorasi makna keseimbangan kerja keluarga pada ibu bekerja. Prosiding Seminar Psikologi \& Kemanusiaan (C) 2015 Psychology Forum UMM, ISBN: 978-979-796-324-8.

Helmle, J. R. (2010). Copreneur and communication: Work family balance in married couple's family businesses (Unpublished doctoral dissertation). University of California, California.

Hill, E. J., Hawkins, A. J., Ferris, M., \& Weitzman, M. (2001). Finding an extra day a week: The positive influence of perceived job flexibility on work family life balance. Family Relations, 50(1), 49-58.

Hill, E. J., Märtinson, V., \& Ferris, M. (2004). Newconcept part-time employment as a work-family adaptive strategy for women professionals with small children. Family Relations, 53(3), 282-292

Jianwei, Z., \& Yuxin, L. (2011). Antecedent of work family conflict: Review and prospect. International Journal of Business Management, 6(1), 89-101.

Keene, J. R., \& Quadagno, J. (2004). Predictors of perceived work-family balance: Gender difference 
or gender similarity. Sociological Perspectives, 47, 1-23.

Kinnunen, U., \& Mauno, S. (1998) Antecedents and outcomes of work-family conflict among employed women and men in Finland. Human Relations, 51(2), 157-162.

Laraseanti, N., \& Aini, I. N. Q. (2009). Dukungan sosial, keseimbangan kerja keluarga dan hasil kerja. Jurnal Bisnis \& Manajemen, 9(1), 33-44.

Lee, N. Y., Zvonkovic, A. M., \& Crawford, D. W. (2013). The impact of work-family conflict and facilitation on women's perceptions of role balance. Journal of Family Issue, 20(10), 1-23.

Lirio, P., Duffy, J. A., Fox, S., Punnet, B. J., Gregory, A., Lituchy, T., \& Santos, N. (2007). Exploring career-life success and family social support of successful women in Canada, Argentina, and Mexico. Career Development International, 12(1), 28-50.

Lyness, K. S., \& Judiesch, M. K. (2008). Can a manager a life and a career? International and multi-source perspective on work life balance and career advancement potential. Journal of Applied Psychology, 93, 789-805.

Lyness, K. S., \&. Kropf, M. B., (2005). The relationships of national gender equality and organizational support with work-family balance: A study of European managers. Human Relations, 58(1), 33-60.

Marcinkus, W. C., Berry, K. S. W., \& Gordon, J. R. (2006). The relationship of social supportto the work family balance and work outcomes of midlife women. Women in Management Review, 22(2), 9425-9464.

Marks, S. R., \& MacDermid, S. M. (1996). Multiple roles and the self: A theory of role balance. Journal of Marriage \& the family, 58, 417-432

Martins L. L., Eddleston, K. A., \& Veiga, J. F. (2002). Moderators of the relationship between work-family conflict and career satisfaction. Academy of Management Journal, 45, 399-409.

McNamara, T. K., Pitt-Catsouphes, M., Matz-Costa, C., Brown, M., \& Valcour, M., (2012). Across the continuum of satisfaction with work-family balance: Work hours, flexibility-fit, and work-family culture. Social Science Research, 42, 283-298.

Muchinky, P. M. (2003). Psychology applied to work. Belmont: Thompson Learning.

Nielson, T. R., Carlson, D. S., \& Lankau, M. J. (2001). The supportive mentor as a means of reducing work family conflict. Journal of Vocational Behavior, 59, 364-381.
Olsen, K. M., \& Dahl, S. A. (2010) Working time: Implications for sickness absence and the work family balance. International Journal of Social Welfare, 19, 45-53. doi: 10.1111/j.1468-2397.20 08.00619.x

Puspitawati, H. (2010). Persepsi peran gender terhadap pekerjaan domestik dan publik pada mahasiswa IPB. Yinyang. Jurnal studi gender \& anak, 5(1), 17-34. Retrieved from http://downloa d.portalgaruda.org/article.php?article $=49180 \&$ val $=3910$.

Puspitawati, H. \& Sari, E.P.M. (2008). Strategi penyeimbangan antara aktivitas pekerjaan dan keluarga pada wanita bekerja di Bogor. Media Gizi dan Keluarga, 1(20), 1-10. Retrieved from http://jamu.journal.ipb.ac.id/index.php/index/searc h/authors/view?firstName $=$ Herien \&middleName $=$ \&lastName $=$ Puspitawati\&affiliation $=\&$ country $=$

Rothbart, N. P. (2001). Enriching or depleting? The dynamic of engagement in work family roles. Administrative Science Quarterly, 46(4), 655-684.

Ruderman, M. N., Ohlott, J. P., Panser, K. \& King, S. N. (2002). Benefits of multiple roles for managerial Women. The Academy of Management Journal, 45(2), 369-386.

Saginak, K. A., \& Saginak, M. A. (2005). Balancing work and family: Equity, gender, and marital satisfaction. The Family Journal, 13,162-166. doi: $10.1177 / 1066480704273230$

Saltztein, A. L. T., \& Saltztein, W. H. (2001). Work family balance and job satisfaction. Public Administration Review, 61, 452-466.

Thomas, L. T., \& Ganster, D. C. (1995). Impact of family-supportive work variables on work-family conflict and strain: A control perspective. Journal of Applied Psychology, 80, 6-15.

Valcour, M. (2007). Work-based resources as moderators of the relationship between hours and satisfaction with work-family balance. Journal of Applied Psychology, 6, 1512-1523.

Voydanoff, P (2004). The effects of work demands and resources on work to family conflict and facilitation. Journal of Marriage and the Family, 66, 398-412.

Washington, F. D., (2006). The relationship between optimistm and work family enrichment and their influence on psychological well being (Unpublished thesis). Drexel University.

Wayne, J. H., Musisca, N., \& Fleeson, W. (2004). Considering the role personality in the work family experience: Relationships of the Big Five to work family conflict and enrichment. Journal 
of Vocational Behavior, 64, 108-130.

Wierda-Boer, H. H., Gerris, J. R. M., \& Vermulest, A. (2008). Adaptive strategies, gender ideology, and work-family balance among Dutch dual earners. Journal of Marriage and the Family, 70(4), 10041014. 